\title{
PERILAKU PEMBELIAN IMPULSIF MAHASISWA DI DAERAH ISTIMEWA YOGYAKARTA
}

\author{
Ascasaputra Aditya*1 \\ Kiki Yulia Pramesty ${ }^{1}$ \\ Winda Puji Lestari ${ }^{1}$ \\ Mohammad Fauzan Irawan ${ }^{1}$ \\ ${ }^{1}$ Program Studi Manajemen, Fakultas Ekonomi, Universitas Widya Mataram, Indonesia
}

\begin{abstract}
This study aims to analyze the level of impulsive buying based on differences in age, gender, and pocket money as well as the types of products purchased impulsively. This research is a form of quantitative research with a survey method. The sample collection technique used random sampling with 158 respondents participating. The analytical tools used are the analysis of the difference test $t$ test, and One-Way ANOVA. The results in this study were there were no differences in impulsive buying in the age group and gender. Meanwhile, pocket money has proven to be different. Buferroni's Post Hoc Test results showed that the group of Rp1,000,000 $R p 2,000,000$ with groups $\geq R p 2,000,001$ had differences, but this difference proved that the low pocket money group was more impulsive than the higher pocket money group. The types of products that are bought impulsively are food, drinks, clothes, and toiletries.
\end{abstract}

Keyword: Age; Gender; Impulsive Buying; Pocket Money

\begin{abstract}
Abstrak
Penelitian ini bertujuan untuk menganalisis tingkat pembelian impulsif didasarkan pada perbedaan usia, jenis kelamin, dan uang saku serta jenis-jenis produk yang dibeli secara impulsif. Penelitian ini merupakan bentuk penelitian kuantitatif dengan metode survey. Teknik pengumpulan sampel menggunakan random sampling dengan 158 responden yang berpartisipasi. Alat analisis yang digunakan, yaitu analisis uji beda $t$ test, dan One-Way ANOVA. Hasil dalam penelitian ini tidak terdapat perbedaan pembelian impulsif pada kelompok usia dan jenis kelamin. Sedangkan pada kelompok uang saku terbukti memiliki perbedaan. Hasil Post Hoc Test Buferroni, menunjukkan bahwa kelompok Rp1.000.000 - Rp2.000.000 dengan kelompok $\geq$ Rp2.000.001 yang memiliki perbedaan, tetapi perbedaan ini membuktikan bahwa kelompok uang saku rendah lebih impulsif dari kelompok uang saku yang lebih tinggi. Jenis produk yang dibeli secara impulsif adalah makanan, minuman, pakaian, dan perlengkapan mandi.
\end{abstract}

Kata kunci: Jenis Kelamin; Pembelian Impulsif; Usia; Uang Saku

Article History: Received: (09-08-2020); Revised: (04-10-2020); and Published: (31-10-2020)

Copyright @ 2020 Ascasaputra Aditya, Kiki Yulia Pramesty, Winda Puji Lestari, Mohammad Fauzan Irawan

How to cite this article: Aditya, A., Pramestya, K.Y., Lestari, W.P., Irawan, F.M (2020). Perilaku Pembelian Impulsif Mahasiswa Di Daerah Istimewa Yogyakarta. Managament Insight: Jurnal IImiah Manajemen. 15(2), 260-273

Retrevied from: https://ejournal.unib.ac.id/index.php/Insight

*Correspondence to: Ascasaputra Aditya $260 \mid \mathrm{H}$ a 1 a $\mathrm{m}$ a $\mathrm{n}$

E-Mail: ascasaputra.feuwmy@gmail.com 


\section{PENDAHULUAN}

Analisis konsumen merupakan salah satu masalah terpenting bagi keberhasilan perusahaan. Hal tersebut dikarenakan tantangan terbesar saat ini adalah memastikan konsumen untuk tidak membeli produk pesaing. Penelitian-penelitian dalam kurun waktu beberapa dekade terakhir telah menekankan pada pentingnya emosi dalam proses pembelian produk dan merk menurut Laros \& Steenkamp (2005). Karena signifikansinya, penelitian tentang perilaku pembelian impulsif telah meningkat dalam beberapa tahun terakhir dan toko ritel mencoba menyesuaikan strategi mereka sesuai dengan kecenderungan ini (Jones et al., 2003).

Pembelian impulsif adalah sikap pembelian yang muncul secara tiba-tiba, spontan, tindakan yang dilakukan seketika, mendesak, dan tidak dapat ditahan, tidak direnungkan, segera dan langsung melakukan pembelian, menurut Rook (1987: 191) dan Rook dan Fisher (1995: 306). Salah satu masalah dalam analisis pembelian impulsif adalah untuk mengetahui faktor-faktor yang memengaruhi perilaku impulsif. Mihić \& Kursan (2010) dan Virvilaitè et al., (2011) menunjukkan bahwa berdasarkan studi empiris dan teoritis, perilaku pembelian impulsif dipengaruhi oleh sejumlah faktor yang berbeda, mulai dari individu, demografis, toko, pengalaman berbelanja, dan budaya. Yang et al., (2011) mengungkapkan bahwa, berbagai faktor pribadi, ekonomi, temporal, budaya dan spasial memengaruhi pembelian impulsif.

Hasil penelitian sebelumnya menemukan bahwa ada perbedaan pembelian impulsif antara kelompok usia muda dengan kelompok usia tua (Činjarević, 2010; Mai et al., 2003, Kosasi, 2014; Mulyono, 2012; Sosianika dan Juliani, 2017, Widawati (2011), dan Aditya, 2014). Hasil penelitian yang berbeda dari Verplanken dan Herabadi (2001), yang menyatakan bahwa, tidak ada perbedaan pembelian impulsif berdasarkan usia. Hal ini diduga karena rentan usia atau jumlah kelompok pada penelitian ini terbatas. Menurut Papalia et al., (2004), remaja berusia antara 11 hingga 20 tahun dalam tingkat penalaran masih berkembang, kreatif, masih berpikir secara abstrak, tingkat emosi atau konsep diri yang masih belum stabil, masih mencari identitas, kurang matang dalam perencanaan atau dalam hal mempertimbangan sesuatu, sehingga perilaku remaja cenderung tidak direnungkan dalam melakukan pembelian. Sedangkan dewasa muda berusia antara 20 hingga 40 tahun sudah memiliki tingkat kepribadian, pengetahuan, penalaran, dan berpikir yang sudah berkembang lebih baik, sehingga perencanaan dan pertimbangan pada usia dewasa muda menjadi lebih baik termasuk dalam melakukan pembelian.

Mahasiswa yang berusia antara 17 - 23 tahun menurut Kasali (1998), masuk dalam kategori masa transisi. Kelompok usia yang masuk dalam masa transisi ini memiliki ciri sebagian besar pendapatan masih rendah, pengeluaran digunakan untuk makan dan hiburan, melanjutkan pendidikan ke tingkat sarjana dengan bantuan biaya orang tua. Kemudian pada kelompok usia 24 - 30 tahun masih menurut Kasali (1998), adalah masa pembentukan keluarga yang memiliki ciri sebagian besar orang dewasa 
mencoba untuk membina rumah tangga, pengeluaran pada masa ini dihabiskan untuk membeli pakaian, aksesoris, makan diluar, hiburan, dan mencari informasi berbagai hal. Karakteristik mahasiswa yang masuk dalam masa transisi dan kurang matang dalam perencanaan menarik bagi peneliti untuk mendalami apakah ada perbedaan dari kelompok usia tersebut.

Selain berdasar usia, perbedaan jenis kelamin juga berpengaruh terhadap cara berperilaku seperti yang dikemukakan oleh Fivush, (1998), dalam Papalia et al., (2004) dan Hyde et al., (2008). Perempuan memiliki sifat lebih emosional atau mengandalkan perasaan dalam berperilaku. Perilaku yang lebih menggunakan perasaan akan sulit untuk menahan keinginan akan sesuatu, maka akan lebih cenderung impulsif. Hasil penelitian Verplanken dan Herabadi pada studi 1 (2001), Činjarević (2010), Widawati (2011), Kosasi (2014), Mulyono (2012), Mai, et al., (2003) dan Aditya (2014) mendukung teori tersebut, bahwa ada perbedaan kecenderungan pembelian perempuan dengan laki-laki. Hasil yang berbeda penelitian oleh Verplanken dan Herabadi pada studi 2 (2001), Widhyanto dan Junaedi (2016), dan Sosianika dan Juliani (2017), bahwa tidak ada perbedaan perilaku impulsif didasarkan jenis kelamin. Hasil berbeda ini karena karakter sosial budaya yang berbeda, Dittmar, et al (1995) dalam Sosianika dan Juliani (2017), bahwa di Indonesia membeli secara berlebihan dianggap tidak baik bagi pria maupun wanita. Sedangkan menurut Widhyanto dan Junaedi (2016) karena kategori produk yang dibeli tidak spesifik berdasar jenis kelamin tertentu.

Selain usia dan jenis kelamin yang telah dipaparkan di atas, perbedaan uang saku menurut Baye (2010) akan memengaruhi perilaku pembelian. Objek pada penelitian adalah mahasiswa karena mahasiswa belum bekerja maka kemampuan membelinya masih bergantung pada uang saku dari orang tua. Stern (1962) berpendapat, bahwa secara umum pembelian impulsif berhubungan dengan kemudahan untuk membeli. Pembelian produk melibatkan sumber daya seperti uang. Pembelian menjadi mudah ketika belanja tidak mempertimbangkan kondisi keuangan, maka pembeliannya menjadi seperti pembelian impulsif. Hal ini menunjukkan bahwa mahasiswa yang uang sakunya tinggi akan cenderung melakukan pembelian impulsif karena memiliki sumber daya yang berlebih atau mudah untuk membeli sesuatu. Hasil penelitian pembelian impulsif berdasarkan uang saku yang di lakukan oleh Sosianika dan Juliani (2017), dan Widawati (2011), yaitu ada perbedaan perilaku pembelian impulsif pada mahasiswa dengan uang saku tinggi dan rendah. Disisi lain, hasil penelitian yang berbeda ditemukan oleh Widhyanto dan Junaedi (2016), Mai, et al., (2003), dan Aditya (2014), bahwa tidak ada perbedaan pembelian impulsif berdasarkan uang saku/pendapatan. Hal tersebut dikarenakan harga produk yang dibeli relatif terjangkau/murah sehingga hampir semua orang dapat membeli karena produk dengan harga murah salah satu pendorong pembelian impulsif, sesuai dengan Stern (1962). 
Pembelian impulsif dapat terjadi di toko ritel, hal ini didukung hasil studi oleh Kollat dan Willet (1969). Menurut Dharmesta dan Handoko (2008), tugas pokok pemasaran adalah mengidentifikasi konsumen untuk barang-barang, menilai kebutuhan konsumen sekarang, serta memperkirakan kebutuhan yang akan datang. Hal ini menarik untuk diteliti tentang jenis produk apa saja yang dibeli secara impulsif pada toko ritel. Hasil penelitian yang telah dilakukan oleh Pradana dan Wahyuningdiyah (2019) produk yang dibeli secara impulsif adalah alat tulis kantor, buah, ice cream, makanan instan, makanan ringan, minuman instan, minuman kemasan, permen/cokelat, produk bayi, produk eletronik, produk kecantikan, produk pembersih, produk pembersih Rumah. Hasil dari Aditya (2014) jenis produk yang dibeli secara impulsif adalah snack coklat, snack asin, pakaian, roti, biscuit, permen, minuman kemasan. Hasil yang berbeda dari penelitian Putra, dkk (2017), adalah pakaian, sepatu, makanan dan minuman, parfum, tas, aksesoris, belanja hobby, otomotif, PC, laptop, flm, otomotif dan video game. Hasil Mai, et al., (2003), baju, barang-barang musik, hadiah. Keberagaman jenis produk yang dibeli secara impulsif berdasarkan hasil penelitian yang telah dikemukakan di atas membuat penulis merasa penting untuk mengetahui jenis-jenis produk yang dibeli secara impulsif.

Berdasarkan pemaparan di atas, maka peneliti tertarik untuk meneliti pembelian impulsif berdasarkan usia, jenis kelamin, dan uang saku. Objek dalam penelitian ini adalah mahasiswa yang pernah melakukan pembeian impulsif di toko ritel. Selain itu, peneliti mencoba untuk mendapat informasi mengenai jenis produk yang dibeli secara impulsif. Oleh karena itu, penelitian ini bertujuan untuk mengetahui perbedaan tingkat pembelian impulsif berdasarkan pada usia, kelompok usia, tingkat pembelian, kelompok jenis kelamin, perbedaan tingkat pembelian impulsif didasarkan pada uang saku, dan jenis produk yang umumnya dibeli oleh mahasiswa di Yogyakarta secara impulsif pada toko ritel.

\section{TINJAUAN PUSTAKA}

\section{Pembelian Impulsif}

Menurut Rock (1987), dan Rook and Fisher (1995), mengatakan bahwa pembelian impulsif merupakan reaksi spontan tanpa memikirkan terlebih dahulu produk yang akan dibelinya, apakah sesuai dengan kebutuhannya. Keputusan pembelian yang dilakukan belum tentu direncanakan lebih dahulu oleh konsumen, sehingga sering timbul pembelian yang tidak terduga akibat adanya rangsangan lingkungan belanja. Pada keputusan pembelian impulsif ada beberapa faktor yang memengaruhi, seperti faktor lingkungan, waktu dan uang (Lin, C.H. \& Lin, H.M., 2005). Menurut Stern (1962), bauran impulsif diklasifikasikan menjadi empat berdasarkan perbedaan situasi pembelian, yaitu: a). Pure Impulse Buying adalah pembelian impulsif diluar pola pembelian yang normal. Pembelian ini terjadi karena ketertarikan produk berdasarkan emosional atau tidak rasional. b). Reminder Impulse Buying adalah 
pembelian impulsif yang muncul ketika pembeli melihat produk dan mengingat bahwa persediaaan produk telah menipis, atau teringat iklan atau informasi tentang produk dan keputusan sebelumnya untuk membeli. c). Suggestion Impulse Buying adalah pembelian impulsif yang muncul ketika pembeli melihat produk saat pertama kali dan membayangkan membutuhkan produk tersebut, meskipun sebelumnya tidak mengetahui pengetahuan tentang produk tersebut. Suggestion impulse buying didasarkan oleh rasional atau fungsi dari produk sedangkan pure impulse buying adalah pembelian impulsif berdasarkan emosional. d). Planned Impulse Buying adalah pembelian impulsif muncul ketika pembeli masuk ke dalam toko dan berpikir akan membeli suatu produk tertentu, tetapi dengan harapan dan niat membeli tergantung harga istimewa, penawaran kupon, dan kesukaan pada produk.

\section{Kecenderungan Pembelian Impulsif}

Menurut Verplanken dan Herabadi (2001), kecenderungan pembelian impulsif seseorang dapat diketahui melalui 2 aspek secara bersama-sama. Dua aspek tersebut adalah aspek kognitif dan aspek afektif. Aspek kognitif meliputi kurangnya rencana dan pertimbangan, sedangkan aspek afektif meliputi perasaan senang, kegembiraan (bersemangat), keharusan, kurangnya kontrol, dan penyesalan. Aspek-aspek tersebut diwujudkan menjadi 20 item pertanyaan, yang kemudian 20 item pertanyaan tersebut menjadi 1 alat ukur kecenderungan pembelian impulsif.

\section{Usia}

Mahasiswa masuk dalam kategori masa transisi, yaitu usia antara 17-23 tahun, yang sebagian besar memiliki ciri pendapatan masih rendah, pengeluaran digunakan untuk makan dan hiburan, melanjutkan pendidikan ke tingkat sarjana dengan bantuan biaya orang tua (Kasali, 1998). Kelompok usia selanjutnya yang berada pada masa pembentukan keluarga adalah usia 24-30 tahun yang memiliki ciri sebagian besar orang dewasa, mencoba untuk membina rumah tangga, pengeluaran pada masa ini dihabiskan untuk membeli pakaian, aksesoris, makan diluar, hiburan, dan mencari informasi berbagai hal (Kasali, 1998).

Hasil penelitian sebelumnya menemukan bahwa ada perbedaan pembelian impulsif antara kelompok usia muda dengan kelompok usia tua (Činjarević, 2010; Mai et al., 2003, Kosasi, 2014; Mulyono, 2012; Sosianika dan Juliani, 2017, dan Aditya, 2014). Papalia et al. (2004) dalam penelitiannya menyatakan bahwa kelompok usia remaja berkisar 11-20 tahun dalam tingkat penalaran masih berkembang, kreatif, masih berpikir secara abstrak, tingkat emosi atau konsep diri yang masih belum stabil, masih mencari identitas maka ini sesuai dengan sifat remaja yang kurang matang dalam perencanaan atau dalam hal mempertimbangan sesuatu, sehingga perilaku remaja cenderung tidak direnungkan dalam melakukan pembelian. Lebih lanjut, pada kelompok dewasa muda yaitu usia 20-40 tahun, tingkat kepribadian, pengetahuan, penalaran, dan berpikir sudah berkembang lebih baik. Hal ini disebabkan kelompok 
dewasa sudah mengenyam pendidikan yang lebih baik, bahkan sudah meniti karir (Kasali, 1998), dengan demikian perencanaan dan pertimbangan pada usia dewasa muda menjadi lebih baik. Berdasarkan hasil tersebut, maka hipotesis dalam penelitian ini dirumuskan sebagai berikut:

Hipotesis 1: Ada perbedaan kecenderungan pembelian impulsif antar kelompok usia.

Hipotesis 2: Kelompok usia muda tingkat pembelian impulsifnya lebih tinggi dari kelompok usia tua.

\section{Jenis Kelamin}

Jenis kelamin menentukan perbedaan dalam berperilaku seperti yang dikemukakan oleh Fivush, (1998), dalam Papalia et al., (2004) dan Hyde et al., (2008). Perempuan cenderung lebih banyak melakukan pembelian impulsif dibandingkan lakilaki. Hal tersebut dikarenakan laki-laki cenderung menghabiskan lebih sedikit waktu untuk berbelanja dan tidak menghabiskan waktu lama di toko, sehingga kecenderungan melakukan pembelian impulsif rendah. Sebaliknya, wanita lebih cenderung melakukan pembelian yang tidak direncanakan, sering kali membeli barang tanpa sebelumnya niat dan juga membeli barang saat berbelanja untuk keperluan lain (Kongakaradecha \& Khemarangsan, 2012).

Adanya perbedaan dalam perilaku pembelian impulsif berdasar pada jenis kelamin juga sejalan dengan hasil penelitian Verplanken dan Herabadi studi 1 (2001), Činjarević (2010), Widawati (2011), Kosasi (2014), Mulyono (2012), Mai, et al., (2003) dan Aditya (2014) mendukung teori tersebut, bahwa ada perbedaan kecenderungan pembelian perempuan dengan laki-laki. Hal tersebut dikarenakan, perempuan memiliki sifat lebih emosional atau mengandalkan perasaan dalam berperilaku dibandingkan dengan laki-laki. Perilaku yang lebih menggunakan perasaan tersebut akan sulit untuk menahan keinginan akan sesuatu, maka akan lebih cenderung impulsif. Berdasarkan hasil tersebut, maka dapat dirumuskan hipotesis sebagai berikut:

Hipotesis 3: Ada perbedaan kecenderungan impulsif berdasar pada jenis kelamin.

Hipotesis 4: Perempuan pembeliannya lebih impulsif dibandingkan laki-laki.

\section{Uang Saku}

Uang saku menurut Kamus Besar Bahasa Indonesia (KBBI) adalah uang yang dibawa untuk keperluan sewaktu-waktu; uang jajan. Stern (1962) berpendapat, bahwa secara umum pembelian impulsif berhubungan dengan kemudahan untuk membeli. Hasil penelitian pembelian impulsif berdasarkan uang saku yang di lakukan oleh Sosianika dan Juliani (2017), dan Widawati (2011), menemukan ada perbedaan perilaku pembelian impulsif pada mahasiswa dengan uang saku tinggi dibandingkan dengan yang lebih rendah. Hal tersebut terjadi karena pembelian produk melibatkan sumber daya seperti uang. Ketika belanja tidak mempertimbangkan kondisi keuangan, maka pembelian impulsif lebih mungkin dilakukan. 
Baye (2010) juga menyatakan perbedaan sumber daya akan memengaruhi perilaku pembelian, dimana seseorang yang memiliki sumber daya berupa uang lebih banyak akan membeli produk dengan harga berapa pun, demikian sebaliknya jika sumber daya berupa uang sedikit, maka tingkat pembeliannya juga turun. Hal ini menunjukkan bahwa mahasiswa yang memiliki uang saku tinggi akan cenderung melakukan pembelian impulsif karena memiliki uang yang berlebih atau mudah untuk membeli sesuatu dibandingkan dengan yang memiliki uang saku rendah. Berdasarkan dari hasil tersebut, maka dapat dirumuskan hipotesis sebagai berikut:

Hipotesis 5: Ada perbedaan kecenderungan pembelian impuslif antar mahasiswa dengan uang saku tinggi dan rendah.

Hipotesis 6: Mahasiswa yang memiliki uang saku lebih tinggi akan lebih impulsif dari kelompok yang tingkat pendapatan atau uang sakunya rendah.

\section{Produk yang Dibeli Secara Impulsif}

Menurut Hansen dan Olsen (2007), seseorang yang memiliki kecenderungan pembelian impulsif akan membeli produk berkaitan dengan convenience product. Convenience product adalah barang konsumsi yang mudah digunakan, dibeli berulangulang, bisa dibeli setiap waktu dan disembarang tempat, dan dengan usaha seminimum mungkin serta tanpa pertimbangan. Menurut Stern (1962), beberapa hal yang berorientasi pada produk yang dapat memengaruhi seseorang membeli produk secara impulsif adalah harga produk murah, mudah ditemukan di toko-toko, produk tidak tahan lama, berukuran kecil dan ringan, dan mudah disimpan.

Produk yang dibeli secara impulsif menurut Magelonsky, (1998) dalam Kacen dan Lee (2002) dan Kottler dan Keller (2012), permen dan majalah termasuk kedalam produk yang dibeli secara impulsif. Menurut Verplanken dan Herabadi (2001), antara lain seperti CD (compact disc), LP (phonograph record), novel, buku studi, komik, pakaian, bunga, parfum, kosmetik, camilan asin, permen batangan, coklat, kue kering, permen, bir Belgian dan minuman anggur. Menurut Aditya (2014) jenis produk yang dibeli secara impulsif adalah snack coklat, snack asin, pakaian, roti, biscuit, permen, minuman kemasan. Hasil penelitian yang telah dilakukan oleh Pradana dan Wahyuningdiyah (2019) produk yang dibeli secara impulsif adalah alat tulis kantor, buah, ice cream, makanan instan, makanan ringan, minuman instan, minuman kemasan, permen/cokelat, produk bayi, produk eletronik, produk kecantikan, produk pembersih, produk pembersih Rumah. Hasil yang berbeda dari penelitian Putra, dkk (2017) yang menyatakan bahwa jenis produk fashion yang sering dibeli secara impulsif. Belanja hobby, otomotif, $P C$, laptop, flm, otomotif dan video game.

Maka hipotesis 7: Produk apa saja yang dibeli secara impulsif di toko ritel. 


\section{METODE PENELITIAN}

Metode penelitian ini merupakan bentuk penelitian kuantitatif. Pengumpulan data dalam penelitian ini menggunakan metode survei yaitu menyebarkan kuesioner (instrumen penelitian) kepada sampel (mahasiswa) yang berdomisili atau terdaftar pada universitas di Yogyakarta (DIY). Ukuran sampel pada penelitian ini sebanyak 158 mahasiswa yang kuliah di Daerah Istimewa Yogyakarta. Teknik pengumpulan data dalam penelitian ini diawali dengan wawancara saat pre test untuk memperoleh jenis produk yang di beli secara impulsif selama dua bulan terakhir. Selanjutnya, kuesioner untuk mengukur tingkat impulsif mahasiswa, menggunakan instrumen penelitian Verplanken's Impulsive Buying Tendency Scale (IBTS), Verplanken dan Herabadi (2001).

Untuk mengukur validitas kuesioner pada penelitian ini menggunakan alat analisis Confirmatory Factor Analysis (CFA) dan uji reabilitas menggunakan Cronbach Alpha untuk mengukur kehandalan indikator dari suatu variabel yaitu usia, jenis kelamin, dan uang saku. Uji beda t-test digunakan untuk menentukan apakah kedua sampel yang tidak berhubungan memiliki rata-rata yang berbeda atau sebaliknya yaitu untuk jenis kelamin dan usia pada tingkat pembelian impulsif, sebelum melakukan uji ini dilakukan uji Levene untuk mengetahui apakah variansi kelompok sama. Uji OneWay ANOVA dalam penelitian ini digunakan untuk menentukan apakah rata-rata dua atau lebih kelompok berbeda, yaitu untuk uang saku, sebelum melakukan uji ini dilakukan uji Levene untuk mengetahui apakah variansi kelompok sama. Jika ditemukan hasil yang berbeda pada kelompok, maka selanjutnya akan di uji dengan Post Hoc Test Bonferroni untuk mengetahui perbedaan setiap pasangan kelompok.

Pada penelitian ini pengelompokkan usia dibagi menjadi 2, yaitu $17-23$ tahun dan $\geq 24$ tahun, kelompok usia ini sesuai dengan karakter mahasiswa berdasar Kasali (1998). Kelompok jenis kelamin dibagi menjadi 2 yaitu perempuan dan laki-laki. Sedangkan untuk pengelompokkan uang saku menjadi 3 kelompok yaitu $\leq$ Rp1.000.000, Rp1.000.001 - Rp2.000.000, dan $\geq R p 2.000 .001$. Untuk jenis produk yang dibeli secara impulsif, peneliti memberikan pertanyaan tertutup dan terbuka. Pertanyaan tertutup merupakan pertanyaan yang jawabannya telah disediakan dalam bentuk multiple choice. Multiple choice yang disediakan diperoleh dari hasil pre test. Sedangkan pertanyaan terbuka adalah pertanyaan yang diisi langsung oleh responden tanpa ada pilihan jawaban. Jawaban responden baik dari pertanyaan terbuka maupun tertutup mengenai jenis produk yang dibeli secara impulsif akan diranking 10 produk yang paling banyak dibeli hingga yang paling sedikit. 


\section{HASIL PENELITIAN}

Hasil uji validitas Confirmatory Factor Analysis (CFA) dengan metode varimax rotation dalam penelitian ini diperoleh nilai Keiser-Meyer-Olkin (KMO) 0,846, ini berarti nilai KMO diatas 0,50 (Ghozali, 2011: 58), maka dapat melakukan analisis faktor. Nilai signifikansi diperoleh 0,000, maka dapat disimpulkan bahwa analisis faktor dapat dilakukan. Hasil uji validitas dapat dilihat pada Tabel 1. Hasil Uji Validitas.

Tabel 1. Hasil Uji Validitas

\begin{tabular}{|c|c|c|c|}
\hline \multirow{2}{*}{ Item } & \multicolumn{2}{|c|}{ Komponen } & \multirow{2}{*}{ Keterangan } \\
\hline & 1 & 2 & \\
\hline P1_recode & & 0,799 & Valid \\
\hline P2_recode & & 0,692 & Valid \\
\hline P3 & 0,626 & & Valid \\
\hline P4_recode & & 0,795 & Valid \\
\hline P5_recode & & 0,760 & Valid \\
\hline P6_recode & & 0,696 & Valid \\
\hline P7_recode & & 0,604 & Valid \\
\hline P8_recode & & 0,830 & Valid \\
\hline $\mathrm{Pg}$ & 0,468 & & Valid \\
\hline P10 & 0,703 & & Valid \\
\hline P11 & 0,606 & & Valid \\
\hline P12 & 0,705 & & Valid \\
\hline P13 & 0,726 & & Valid \\
\hline P14_recode & & 0,519 & Valid \\
\hline P15 & & $-0,486$ & Valid \\
\hline P16 & 0,624 & & Valid \\
\hline P17 & 0,595 & & Valid \\
\hline P18 & 0,626 & & Valid \\
\hline P19 & 0,762 & & Valid \\
\hline P20 & 0,757 & & Valid \\
\hline
\end{tabular}

Sumber: Data diolah (2020)

Hasil uji reliabilitas menunjukkan nilai Cronbach's Alpha 0,790, maka item pertanyaan ini dinyatakan handal (reliabel) untuk mengukur kecenderungan pembelian impusif sehingga dapat digunakan sebagai alat analisis. Hasil dapat dilihat pada tabel 2.

Tabel 2. Hasil Uji Reliabilitas

\begin{tabular}{cc}
\hline Cronbach's Alpha & Keterangan \\
\hline 0,790 & Reliabel \\
\hline
\end{tabular}

Sumber: Data diolah peneliti (2020)

Tabel 3. Hasil Penelitian

\begin{tabular}{|c|c|c|c|c|c|c|c|}
\hline Variabel & Kategori & $\begin{array}{l}\text { Jumlah } \\
\text { responden }\end{array}$ & $\begin{array}{c}\text { Pesentase } \\
(\%)\end{array}$ & Mean & $\begin{array}{c}\text { Std. } \\
\text { Deviation }\end{array}$ & $t$-test & $\begin{array}{c}\text { One-Way } \\
\text { ANOVA }\end{array}$ \\
\hline Usia & $17-23$ tahun & 146 & 92,4 & 2,6784 & 0,48080 & $\begin{array}{c}F \\
\text { (Levene's) } \\
=0,073 \\
\text { Sig. } \\
\text { (Levene's) } \\
=0,787\end{array}$ & - \\
\hline
\end{tabular}




\begin{tabular}{|c|c|c|c|c|c|c|c|}
\hline Variabel & Kategori & $\begin{array}{l}\text { Jumlah } \\
\text { responden }\end{array}$ & $\begin{array}{c}\text { Pesentase } \\
\text { (\%) }\end{array}$ & Mean & $\begin{array}{c}\text { Std. } \\
\text { Deviation }\end{array}$ & t-test & $\begin{array}{c}\text { One-Way } \\
\text { ANOVA }\end{array}$ \\
\hline \multirow{7}{*}{$\begin{array}{l}\text { Jenis } \\
\text { Kelamin }\end{array}$} & & & & & & $t=0,286$ & \\
\hline & $\geq 24$ tahun & 12 & 7,6 & 2,6375 & 0,41622 & Sig. $=$ & - \\
\hline & Total & 158 & 100 & & & 0,775 & \\
\hline & Perempuan & 103 & 65,2 & 2,6549 & 0,50626 & $\begin{array}{c}F \\
\text { (Levene's) } \\
=1,484 \\
\quad \text { Sig. } \\
\text { (Levene's) } \\
=0,225\end{array}$ & - \\
\hline & & & & & & $t=-0,740$ & \\
\hline & Laki - Laki & 55 & 34,8 & 2,7136 & 0,41225 & Sig. $=$ & - \\
\hline & Total & 158 & 100 & & & 0,461 & \\
\hline \multirow{4}{*}{$\begin{array}{l}\text { Uang } \\
\text { Saku }\end{array}$} & $\begin{array}{c}\leq \\
\text { Rp1.000.000 }\end{array}$ & 104 & 65,8 & 2,6457 & 0,43243 & - & $\begin{array}{l}\text { Levene } \\
\text { Statistic = } \\
2,484 \\
\text { Sig. } \\
\text { Homogeneity }\end{array}$ \\
\hline & & & & & & & $=0,087$ \\
\hline & $\begin{array}{c}\text { Rp1.000.001 } \\
- \\
\text { Rp2.000.000 }\end{array}$ & 44 & 27,8 & 2,8193 & 0,50362 & - & $F=4,787$ \\
\hline & $\begin{array}{c}\geq \\
\text { Rp2.000.001 } \\
\text { Total }\end{array}$ & $\begin{array}{c}10 \\
158\end{array}$ & $\begin{array}{l}6,3 \\
100\end{array}$ & 2,3500 & 0,59768 & - & Sig. $=0,010$ \\
\hline
\end{tabular}

Sumber: Data diolah peneliti (2020)

\section{PEMBAHASAN}

Hasil uji t-test, diperoleh nilai Levene's test adalah 0,073 dengan signifikansi $0,787>0,05$, maka variansi kedua kelompok sama. Nilai $t=0,286$ dengan signifikansi $0,775>0,05$, maka tidak ada perbedaan antara kelompok usia 17-23 tahun (mean = 2,6784 ) dengan kelompok $\geq 24$ tahun (mean $=2,6375$ ), walaupun nilai mean lebih tinggi kelompok usia 17-23 dari kelompok $\geq 24$ tahun tetapi tidak terbukti ada perbedaan. Hal tersebut sesuai dengan penelitian Verplanken dan Herabadi (2001) yang menemukan bahwa usia tidak teruji signifikan terhadap pembelian impulsif. Oleh karena itu, Hipotesis 1 dan Hipotesis 2 dalam penelitian ini ditolak. Hasil ini diduga karena jumlah pembagian kelompok usia tidak banyak, hanya ada 2 kelompok. Hal lain kelompok usia $\geq 24$ tahun terdiri dari 12 mahasiswa, Sebagian besar berusia 24 tahun, diduga pada usia ini karakternya sama dengan usia 17 - 23 tahun, masih menjadi mahasiswa sehingga perilaku pembeliannya sama. Hasil dapat dilihat pada tabel 3.

Hasil uji $t$-test, diperoleh nilai Levene's test adalah 1,484 dengan signifikansi $0,225>0,05$, maka variansi kedua kelompok sama. Nilai $t=-0,740$ dengan signifikansi $0,461>0,05$, maka tidak ada perbedaan antara perempuan ( mean $=2,6549$ ) dan lakilaki (mean = 2,7136). Hasil ini sesuai dengan Verplanken dan Herabadi studi 2 (2001), Widhyanto dan Junaedi (2016), dan Sosianika dan Juliani (2017), bahwa tidak ada 
perbedaan perilaku impulsif didasarkan jenis kelamin. Hasil ini diduga disebabkan karakter sosial budaya yang berbeda, Dittmar, et al (1995) dalam Sosianika dan Juliani (2017), bahwa di Indonesia membeli secara berlebihan dianggap tidak baik bagi pria maupun wanita. Sedangkan menurut Widhyanto dan Junaedi (2016) karena kategori produk yang dibeli tidak spesifik berdasar jenis kelamin tertentu. Dengan demikian, Hipotesis 3 dan Hipotesis 4 dalam penelitian ini ditolak. Hasil dapat dilihat pada tabel 3.

Hasil uji One-Way ANOVA, diperoleh nilai Levene's test adalah 2,484 dengan signifikansi 0,087 $>0,05$, maka variansi ketiga kelompok sama. Nilai $F=4,787$ dengan signifikansi 0,010 <0,05, maka ada perbedaan antara ketiga kelompok uang saku. Hasil ini sesuai dengan Sosianika dan Juliani (2017) dan Widawati (2011). Dilihat dari hasil Post Hoc Test Bonferroni (untuk melihat perbedaan antar pasangan kelompok), hasilnya menunjukan bahwa yang memiliki perbedaan hanya kelompok Rp1.000.000 Rp2.000.000 (mean $=2,8193$ ) dengan kelompok $\geq R p 2.000 .001$ ( mean $=2,3500$ ) dengan nilai signifikansi 0,013. Maka dapat dikatakan bahwa responden dengan pendapatan Rp1.000.000 - Rp2.000.000 lebih impulsif dari kelompok pendapatan $\geq$ Rp2.000.001. Hal yiini sesuai dengan Sosianika dan Juliani (2017). Dengan demikian, hipotesis 5 dalam penelitian ini diterima sedangkan Hipotesis 6 ditolak, sesuai Widhyanto dan Junaedi (2016), Mai, et al., (2003), dan Aditya (2014). Hal ini diduga terbatasnya responden kelompok $\geq$ Rp2.000.001. Hasil dapat dilihat pada tabel 3 .

Hasil dari penelitian, diperoleh 10 terbanyak yang diurutkan dari yang tertinggi ke terendah jenis produk yang dibeli secara impulsif secara pertanyaan tertutup yaitu susu (98 responden), air mineral ( 83 responden), tisu ( 82 responden), snack asin (78 reponden), biskuit (77 responden), skincare (53 reponden), minuman soda (40 responden), dan coklat (37 responden). Dengan demikian jenis produk susu yang paling banyak dibeli oleh responden secara impulsif. Sedangkan hasil penelitian untuk 10 terbanyak jenis produk yang dibeli secara impulsif secara pertanyaan terbuka yng diurutkan dari yang tertinggi ke terendah adalah mie instan (11 responden), sabun (11 responden), pakaian ( 6 responden), beras (5 reponden), buah (5 responden membeli), air mineral (4 reponden), kopi 4 responden), barang sembako (4 responden), shampo (4 responden), dan tisu (4 responden). Dengan demikian jenis produk mie instan yang paling banyak dibeli oleh responden secara impulsif. Maka Hipotesis 7 sesuai dengan Verplanken dan Herabadi (2001), Aditya (2014), Putra, dkk (2017), dan Pradana dan Wahyuningdiyah (2019) yang menemukan bahwa makanan, minuman, pakaian, dan perlengkapan mandi adalah jenis produk yang sering dibeli secara impulsif. Hal ini dikuatkan oleh Hansen dan Olsen (2007), dan Stern (1962), produk yang dibeli secara impulsif memiliki karakter produk seperti mudah digunakan, dibeli berulang-ulang, bisa dibeli setiap waktu, mudah didapatkan, harga murah, produk tahan lama, dan mudah disimpan. 


\section{KESIMPULAN DAN SARAN}

Secara umum, penelitian ini memberikan gambaran mengenai tingkat kecenderungan perbedaan pembelian impulsif didasarkan pada usia, jenis kelamin dan uang saku. Hasil penelitian menunjukan bahwa tidak ada perbedaan pembelian impulsif berdasarkan usia dan jenis kelamin maka sesuai dengan Verplanken dan Herabadi (2001), Widhyanto dan Junaedi (2016), dan Sosianika dan Juliani (2017). Hal ini disebabkan karena jumlah kelompok usia terbatas yakni hanya 2 kelompok dan selisihnya usianya tidak banyak sehingga cenderung memliki perilaku yang sama baik perempuan maupun laki-laki. Dilihat dari uang saku, diperoleh hasil penelitian bahwa terdapat perbedaan antara mahasiswa, hal ini sesuai dengan Sosianika dan Juliani (2017) dan Widawati (2011). Hasil Post Hoc Test (Bonferroni), yang teruji berbeda hanya pada kelompok Rp1.000.000 - Rp2.000.000 dengan $\geq$ Rp2.000.001 dimana kelompok uang saku rendah lebih impulsif dari kelompok uang saku yang lebih tinggi. Kelompok $\geq$ Rp2.000.001 tidak terbukti memiliki tingkat impulsif diduga karena terbatasnya jumlah responden uang saku Kelompok $\geq$ Rp2.000.001 yang diperoleh. Ini sesuai dengan Widhyanto dan Junaedi (2016), Mai, et al., (2003), dan Aditya (2014). Hasil analisis jenis produk yang dibeli secara impulsif dalam penelitian ini berdasar pada pertanyaan tertutup dan terbuka didominasi produk kategori makanan, minuman dan pakaian.

Pada penelitian ini hanya membahas tetang pembelian impulsif yang didasarkan variabel demografi yang terdiri dari usia, jenis kelamin, dan uang saku karena objek penelitian ini mahasiswa. Penelitian selanjutnya lebih fokus tentang analisis faktor-faktor yang memengaruhi pembelian impulsif mahasiswa tanpa membedakan jenis kelamin. Pada usia ini karakter mereka sama karena rentang usia para mahasiswa tidak terlalu tinggi.

\section{DAFTAR PUSTAKA}

Aditya, A. (2014). Kecenderungan pembelian impulsif didasarkan pada variabel demografi: Studi di Yogyakarta. Tesis. Universitas Gadjah Mada.

Baye, M. C. (2010). Managerial Economics and Business Strategy. 7th ed. Mc Graw-Hill. New York. USA.

Činjarević, M. (2010). Cognitive and Affective Aspects of impulse Buying. Sarajevo Business and Economics Review. 30: 168-185.

Dharmesta, B.S. dan Handoko, H. (2008). Manajemen Pemasaran: Analisis Perilaku Konsumen, ed 1. Yogyakarta: BPFE.

Ghozali, I. (2011). Aplikasi analisis multivariate dengan program IBM SPSS 19, ed5. Semarang: Badan penerbitan Universitas Diponegoro.

Hair, J. F. Jr., Black, W. C., Babin, B. J., Anderson, R. E., \& Tatham, L. R. (2010). Multivariate Data Analysis, $7^{\text {th }}$ edd. Upper Saddle River: Pearson Prentice. 
Hansen, K. and Olsen, S.O. (2007). Impulsive Buying Behaviour: The Role of Impulse Buying Tendencies and Convenience Orientation. ANZMAC 2007 Conference.3-5 December 2007, New Zealand. pp. 2199-2205.

Hyde, J. S., Mezulis, A. H., and Abramson, L. Y. (2008). The ABC of Depression: Integrating Affective, Biological, and Cognitive Models to Explain the Emerge of the Gender Difference in Depression. Psychological Review. 115:291-313.

Jones, M.A., Reynolds, K.E., Weun, S., and Beatty, S.E., (2003). The product-specific nature of impulse buying tendency. Journal of Business Research 56 (2003) 505511.

Kacen, J. J. and Lee, J. A. (2002). The Influence of Culture on Consumer Impulsive Buying Behavior. Journal of Consumer Psychology. 12:163-176.

Kasali, R (1998). Membidik Pasar Indonesia Segmentasi, Targeting, dan Posisioning. Jakarta: Gramedia Pustaka Utama.

Kamus Besar Bahasa Indonesia (2016). Diakses pada tanggal 27 September 2020 https://kbbi.kemdikbud.go.id/entri/

Kollat, D. T. and Willet, R. P. (1969). Is Impulsif Purchasing Really a Useful Concept for Marketing Decision?. Journal of Marketing. 33: 79-83.

Kongakaradecha, S. and Khemarangsan, Dr. A. (2012) "A Pilot Study Of ImpulseBuying Behavior in Bangkok, Thailand", the 2nd National and International Graduate Study Conference 2012, Graduate School Silpakorn University, Thailand

Kosasi, W. H. (2014). Analisa Pengaruh Faktor Demografi Dan Promosi Terhadap Munculnya Impulse Buying Produk Keetori di Surabaya. Jurnal Manajemen Pemasaran Petra. 2:1-8.

Laros, F.J.M. and Steenkamp, J.E.M. (2005). Emotions in comsumer behavior: a hierarchical approach. Journal of Business Research 58 (2005) 1437 - 1445.

Lin, C.H. and Lin, H.M. (2005). An exploration of Taiwanese adolescents' impulse buying tendency. Adolescence;Spring. 40:157, p215-223.

Mai, N. T. T., Jung. K., Lantz, G., dan Loeb, S. A. (2003). An Explanatory Investigation into Impulse Buying Behavior in a Transitional Economy: A Study of Urban Consumer in Vietnam. Journal of International Markteting. 11: 13-55.

Mulyono, F. (2012). Faktor Demografis Dalam Perilaku Pembelian Impulsif. Jurnal Administrasi Bisnis. 8:88-105.

Pradana, A. A. dan Wahyuningdyah, R. Y. (2019). Analisis pengaruh potongan harga, paket bonus, pajangan dalam toko dan suasana toko terhadap perilaku pembelian impulsif pada pelanggan minimarket Indomaret hybrid di Kota Semarang. Jurnal Ekonomi, Manajemen, Akuntansi dan Perpajakan.2 (1): 64.

Papalia, D. E., Olds, S. W. and Feldman, R. D. (2004). Human Development. 9th ed. McGraw-Hill. New York. USA. 
Putra, A. H. P. K., Said, S., dan Hasan, F. (2017). Pengaruh karakteristik toko dan produk bagi konsumen di Indonesia terhadap pembelian impulsif.Jurnal Manajemen \& Kewirausahaan. 5 (2). 8 - 19.

Rook, D. W. (1987). The Buying Impulse. Journal of Consumer Research. 14:189-199.

Rook, D. W. and Fisher, R. J. (1995). Normative Influences on Impulsive Buying Behavior. Journal of Consumer Research. 22:305-313.

Sosianika, A. dan Juliani, N. (2017). Studi perbedaan perilaku pembelian impulsif berdasarkan karakteristik konsumen. Sigma-Mu. 9 (1): 17.

Stern, H. (1962). The Significance of Impulse Buying Today. Journal of Marketing. 26:59-62.

Verplanken, B. and Herabadi, A. (2001). Individual Differences in Impulsive Buying Tendency: Feeling and no Thinking. European Journal of Personality. 15:S71S83.

Virvilaitè, Regina; Saladienè, Violeta and Žvinklytè Jūratė. (2011). "The Impact of External and Internal Stimuli on Impulsive Purchasing", Economics and Management (Ekonomika Ir Vadyba): 2011, Vol. 16, pp. 1329-1336

Widawati, L. (2011). Analisis Perilaku "Impulse Buying" dan "Locus of Control" pada Konsumen di Carrefour Bandung. Mimbar. 37:125-132.

Widhyanto, G. D. dan Junaedi, M. F. S. (2016). Studi tipe perilaku pembelian impulsif pada konsumen generasi Y. Jurnal Universitas Atma Jaya Yogyakarta. 1-15.

Yang, Dong-Jenn; Huang, Kuang Chuan and Feng, Xuanxiaoqing. (2011). "A Study of the Factors that Affect the Impulsive Cosmetics Buying of Female Consumers in Kaohsiung", International Journal of Business and Social Science, Vol. 2 No. 24, pp. $275-282$ 